\title{
STEFAN MORAWSKI O FILMIE I KRYTYCE FILMOWEJ
}

Stefan Morawski about film and film criticism

\begin{abstract}
The author undertook the task of describing the views of Stefan Morawski as a film critic. Morawski appreciated realistic films the most. He understood realism as a film style that gives an image of the real life of ordinary people. Looking at the film from a Marxist perspective, he described it in a historical context. In his interpretations of the films, Morawski tried to reveal their moral message. He called for the creation of films that would mobilize viewers to work for a better world. In the second part of the article, the considerations concern Morawski's metacritical publications. Morawski described many types of film criticism. He explained the relationship between film criticism and aesthetics.
\end{abstract}

Keywords: film criticism, film realism, Marxism

Problematyka filmowa w publikacjach Stefana Morawskiego rozkłada się na cztery płaszczyzny. Pierwsza obejmuje recenzje filmowe, druga - refleksję metakrytyczną, trzecia - udział w dyskusjach, czwarta zaś - analizy i komentarze tekstów z zakresu wiedzy o filmie i mediach audiowizualnych. Skupiłem uwagę na recenzjach i rozważaniach o krytyce filmowej. Recenzje najbardziej bezpośrednio dotyczą postawy estetycznej Morawskiego, a uwagi metakrytyczne stanowią ważny komentarz do rezultatów jej stosowania w obcowaniu z filmem. Pominąłem dyskusje, w które angażował się Morawski, ponieważ wydobycie z nich jedynie jego głosu nie daje obrazu całości. Ta płaszczyzna aktywności moim zdaniem zasługuje na odrębne opracowanie, w którym będzie można nakreślić kontekst niezbędny do zrozumienia jej znaczenia. Z kolei analizy zagadnień z obszaru teorii filmu przesuwają punkt zainteresowania z estetyki na metodologię badań filmoznawczych. Przybliżenie Czytelnikowi tej płaszczyzny w tym zbyt krótkim jak na ilość zebranego materiału tekście dałoby rezultat powierzchowny. 


\section{Film realistyczny}

W wydanej w roku 1955 książce Jak patrzeć na film Stefan Morawski wyznaje we Wstępie, że celem tej publikacji jest popularyzowanie wartościowych filmów. Swoje rozważania skierował do widzów zainteresowanych nie tylko przyjemnym spędzeniem (chociaż ich nie pomija) czasu w kinie, lecz również do widzów potrzebujących rozmowy, przedyskutowania wrażeń, przemyśleń i rozwiania wątpliwości. Realizując postawione sobie zadanie wskazania filmów godnych obejrzenia i sposobu ich interpretacji, Morawski wysunął na plan pierwszy film realistyczny. Wyjaśniając znaczenie tego pojęcia, pisał:

Realizm jest metodą twórczą, to znaczy pewnym określonym sposobem widzenia i interpretowania zjawisk przez artystę. Realista odzwierciedla rzeczywistość w najszerszym tego słowa znaczeniu, to jest zarówno działania, jak i przeżycia ludzkie, zarówno przedmioty, jak i sytuacje, zarówno przyrodę, jak i człowieka ${ }^{1}$.

Ale - dodaje Morawski - zapisywanie przypadkowego potoku życia nie mieści się w metodzie realistycznej. Wymaga ona od artysty dotarcia do istoty obserwowanej rzeczywistości. Aby to osiągnąć, musi on gruntownie poznać ludzi, ich postawy i sytuacje życiowe. Zebrana wiedza pozwoli artyście wybrać elementy najbardziej reprezentatywne dla rzeczywistości, którą zamierza oddać w swoim filmie. Elementy te Morawski nazywa typowymi. Typowość nie oznacza przeciętności, jakiegoś zobrazowania średniej statystycznej. To jest spojrzenie powierzchowne. Morawski wyjaśnia, że typowość ma syntetycznie wyrażać pogłębioną analizę: „(...) właściwa dla sztuki typowość nie jest wyłącznie sprawą słusznej ideologii. Typowość to ujrzenie głównych konfliktów ideowych danego czasu w ludziach, w ich przeżyciach i działaniach, w ich wzajemnych powiązaniach"2. Nie znaczy to, że film realistyczny ma się wyczerpywać w funkcji poznawczej. Nie różniłby się od filmów instruktażowych lub oświatowych. Unieważniona zostałaby jego rola jako dzieła sztuki. Realistyczne dzieło sztuki filmowej ma nieść ładunek zarówno poznawczy, jak i emocjonalny. Morawski pisze: „W dziele filmowym, jak w każdym dziele sztuki, racje rozumowe wiążą się jak widać z racjami uczuciowymi. Dzieje się tak dlatego, że typowe przejawia się w indywidualnym, że konflikt idei jest tutaj ukazany poprzez konflikt charakterów i działań żywych ludzi"”3.

Aby powiązać w filmie jego wartości poznawcze i emocjonalne, twórca musi nadać mu właściwą formę. Oczywiście - właściwą w obrębie realizmu. W skrypcie poprzedzającym książkę o odbiorze filmu Morawski wyjaśnił, że w marksistowskiej analizie realistycznego dzieła sztuki nie rozdziela się treści od formy ${ }^{4}$. Dia-

\footnotetext{
S. Morawski, Jak patrzeć na film, Filmowa Agencja Wydawnicza, Warszawa 1955, s. 29. Ibidem, s. 32.

Ibidem, 47.

Zob. S. Morawski, Szkice z podstawowych zagadnień estetyki marksistowskiej, Państwowy Instytut Sztuki, Warszawa 1952.
} 
lektyczne ujęcie odsłania ich ścisłe przyleganie do siebie, co wyraża się w pojęciu „treścio-formy”5. Treścią jest „materiał dający się jawnie, bezpośrednio odnieść do określonych obiektywnych desygnatów", formą zaś są środki wyrazu, które składają się na styl dzieła ${ }^{6}$. Desygnat, który w sztuce realistycznej wysuwa się na pierwszy plan, to człowiek. Estetyka marksistowska postuluje, aby desygnowany człowiek przedstawiony był w konkretnych warunkach społeczno-ekonomicznych, a nie w sposób uniwersalistyczny - człowiek w ogóle. Rezultatem tego postulatu jest normatywne narzucenie prymatu treści nad formą ${ }^{7}$.

Wyjaśniając kwestię powiązania treści i formy w filmie, Morawski powołał się na Jerzego Toeplitza, który zwrócił uwagę na polifoniczność filmu ${ }^{8}$. Pojęcie to rodzi dwojakie skojarzenia. $Z$ jednej strony odsyła do polifonicznego współdziałania elementów filmu, o którym pisał Roman Ingarden. Z drugiej jest przypomnieniem koncepcji montażu polifonicznego opracowanej przez Siergieja Eisensteina. Morawski pominął wprawdzie postawioną przez Ingardena tezę o polifonii ,heterogenicznych elementów i odpowiednich jakości wartościowych"9, która powstaje w rezultacie percepcji warstwy zrekonstruowanych wyglądów wzrokowych i warstwy przedmiotów przedstawionych, ale nawiązał do charakterystyki dzieła filmowego jako syntezy sztuk. Ingarden zwrócił uwagę, że w widowisku filmowym splatają się środki wyrazowe różnych sztuk, dając ,twory całkiem osobliwe" ${ }^{10}$. Widowisko tego rodzaju rodzi się na pograniczu literatury, malarstwa, przedstawienia teatralnego i kompozycji muzycznej. Morawski powtórzył tę tezę, pisząc: „Na sztukę filmową złożyło się wiele sztuk. To prawda. Nie są przecież odkryciem filmu takie elementy, jak zdjęcia, gra aktorska, kompozycja muzyczna czy plastyka. Wszystkie je znamy z fotografiki, teatru, muzyki, plastyki" 11 , ale Morawski dodał nowe pojęcie, o którym Ingarden nie wspomniał: montaż. Polifonię tworzy montaż. W ten sposób Morawski sięgnął do pojęcia montaż polifoniczny, które wprowadził Eisenstein ${ }^{12}$. Ten typ montażu polegał na łączeniu i przeplataniu się wrażeń zmysłowych wywołanych filmowymi środkami wyrazu.

W rezultacie przeprowadzonych rozważań Morawski radził czytelnikom, aby oglądali filmy realistyczne, czyli takie, w których przedstawiona została prawda życiowa. Rzecz jasna musi to być prawda życiowa grupy społecznej (klasy, warstwy) najbardziej reprezentatywnej dla danego okresu historycznego. Ponieważ każdy

Ibidem, s. 208.

Zob. ibidem, s. 220-221.

Zob. ibidem, s. 226-227.

Zob. S. Morawski, Jak patrzeć na film, op. cit., s. 55.

9 R. Ingarden, O dziele literackim. Badania z pogranicza ontologii, teorii języka i filozofii literatury, przeł. [z niem.] M. Turowicz, Państwowe Wydawnictwo Naukowe, Warszawa 1988, s. 404.

10 Idem, Kilka uwag o sztuce filmowej [w:] A. Helman (red.), Estetyka i film, Wydawnictwa Artystyczne i Filmowe, Warszawa 1972, s. 205.

11 S. Morawski, Jak patrzeć na film, op. cit., s. 56.

12 Zob. S. Eisenstein, Nieobojętna przyroda, przeł. M. Kumorek, Wydawnictwa Artystyczne i Filmowe, Warszawa 1975. 
utwór artystyczny wyrasta z warunków społeczno-ekonomicznych czasu, w którym powstał, to w połowie lat 50. XX wieku najbardziej reprezentatywną klasą byli robotnicy zatrudnieni w przemyśle. Wśród filmów realistycznych najbardziej wartościowe są utwory artystyczne. Rozpoznać je można po harmonijnym połączeniu ich treści ze środkami wyrazu. Gdy widzowie zaangażują się intelektualnie i emocjonalnie w przeżycie artystycznego filmu realistycznego, to spełni on funkcję postępową, czyli będzie budował i wzmacniał świadomość rewolucyjnych przemian skierowanych przeciwko krzywdzie społecznej ${ }^{13}$.

\section{Film realistyczny w ocenie krytyka do przełomu lat 50. i 60. XX wieku}

Rady, jakich udzielił Morawski czytelnikom wspomnianej książki, nie wynikały jedynie z przemyśleń estetyka, lecz były silnie osadzone w pracy krytyka filmowego. Korzystając z posiadanych przeze mnie danych bibliograficznych, wyliczyłem, że w latach 1948-1956 Morawski napisał dla „Gazety Krakowskiej”, „Echa Krakowa” i „Echa Tygodnia” 245 recenzji oraz sprawozdań z przeglądów i festiwali filmowych ${ }^{14}$. Nie sposób w tym zbyt krótkim jak na bogactwo dorobku jego bohatera tekście opisać wszystkich tych publikacji. Przywołam niektóre z nich, aby pokazać gust krytyka. Szczególną wagę mają pod tym względem wczesne recenzje.

Od początku swojej drogi krytyka Morawski jasno wyrażał towarzyszące mu nastawienie aksjologiczne. Odrzucał filmy epatujące widza sensacją i erotyką, które wywołują u odbiorcy wrażenie wszechogarniającego świat zła i demoralizacji. Ich bohaterowie są odrealnieni, całkowicie skupieni na własnych przeżyciach lub zdobywaniu fortuny. Filmy tego rodzaju nie dają widzowi żadnych pozytywnych wzorów do naśladowania. Przyciągają do kin obietnicą skosztowania zakazanego owocu, ale w rzeczywistości ich głównym celem jest powiększanie dochodów producentów filmowych. Morawski dostrzegał nieliczne wartościowe filmy zachodnie - na przykład Nietolerancja w reżyserii Davida Warka Griffitha lub Monsieur Verdoux Charlesa Chaplina $^{15}$ - ale w większości ówczesny anglosaski i francuski film jawił mu się jako ,(...) pełen pesymizmu, patrzący wstecz, zrezygnowany. Przede wszystkim jest

13 Zob. S. Morawski, Jak patrzeć na film, op. cit., s. 86.

$14 \mathrm{~W}$ autorefleksji na temat własnej pracy w gazecie codziennej w roli recenzenta Morawski wyznał: „Sądzę, że największym błędem mej pracy było pisanie zbyt wielu recenzji. Pisanie recenzji co kilka dni, przy natłoku wrażeń, nie pozwala na gruntowne przetrawienie filmu. Wydaje się, że ilość recenzji nie powinna przekraczać 5-6 na miesiąc, a ja - bywało tak! - pisałem 9-11'. S. Morawski, O krytyce filmowej w piśmie codziennym, „Przegląd Kulturalny” 1953, nr 13 (31), s. 4.

15 Zob. S. Morawski, Dlaczego filmy radzieckie sa dobre, „Echo Krakowa” 1948, nr 285 (934), s. 3; Nietolerancja (Intolerance: Love's Struggle Throughout the Ages), reż. David Wark Griffith, prod. 1916, prem. 5 września 1916, USA; Monsieur Verdoux, reż. Charles Chaplin, prod. 1947, prem. 11 kwietnia 1947, USA. 
chory. Pokazuje anomalia [sic!], gdyż taki jest w istocie tamten świat, który tyle mówi o «obronie dorobku kulturalnego ludzkości», a niszczy go z dnia na dzień"16.

Morawski cenił filmy o zwykłych ludziach, ponieważ uważał, iż to one przedstawiają życie widzów. Oglądając film „o sobie”, widz powinien przemyśleć swoją rolę w społeczeństwie i dążyć do jej poprawienia. Dlatego obok krytycznego spojrzenia na rzeczywistość film musi zawierać pozytywne przesłanie, wskazanie ideału, w którego realizację widz powinien zaangażować się po seansie. Zdaniem Morawskiego ów cel wychowawczy doskonale spełnia dokumentalny film Turksib w reżyserii Wiktora Turina: „Przytoczę jako przykład wychowawczej roli filmu bodźcowy pokaz filmu Turksib w r. 1930 o odbudowie dla mieszkańców tego miasteczka kolejowego traktu. Nazajutrz po filmie przystąpili oni do roboty i trakt ten dobudowali" ${ }^{17}$. Morawski aprobował bohaterów optymistycznych, którzy nie ulegają trudnościom, ale śmiało podejmują nawet ryzykowne zadania. W swojej aktywności są gotowi do współpracy i niesienia pomocy innym. Ich energia życiowa nie jest skierowana na sukces materialny lub wyżycie w sferze seksualnej, ale służy pracy. Morawski chciał, aby bohater pracujący, który własnymi rękami tworzy coś nowego, użytecznego dla członków społeczeństwa, stał się wzorem dla widzów. Te wartości odnalazł w filmach radzieckich. Przynajmniej w niektórych, bo przecież, jak sam przyznał, „nie wszystkie filmy radzieckie są świetne"18.

Z dzisiejszej perspektywy wydaje się dziwne, że Morawski kwalifikował radzieckie filmy propagandowe lub co najmniej mocno propagandą nasycone jako filmy realistyczne. Wszak po drugiej połowie lat 40. XX wieku trudno było wierzyć, że przedstawiają one realny obraz życia w ZSRR. Tym natomiast, co moim zdaniem silnie go poruszyło, była ich poetyka. Trzeba wziąć pod uwagę, że filmowcom radzieckim udało się wypracować styl, który pozwalał odróżnić ich utwory od filmów wyprodukowanych w pozostałych kinematografiach świata. Najlepsze z nich oddziaływały na widza z ogromną siłą, czego dowodem było niewpuszczenie ich na ekrany w wielu państwach kapitalistycznych lub zmuszanie dystrybutorów do wprowadzenia zmian, które niwelowały ich rewolucyjne przesłanie. Gdyby zawarta w tych filmach ideologia komunistyczna nie została wyrażona w sposób poruszający emocje i perswazyjnie skuteczny, to zapewne nie spotkałyby się one z takim oporem. Można przypuszczać, że ów radziecki styl i siła jego oddziaływania, porównywalna, a może nawet większa niż wrażenia wywołane przez najlepsze filmy hollywoodzkie, musiały zaintrygować Morawskiego.

Nietrudno wykazać, że Morawski w swoich recenzjach bardziej kierował się wartościami artystycznymi i estetycznymi niż ich artykulacją w wytworach danej kinematografii (np. radzieckiej). Gdy zetknął się z cenionymi przez siebie wartościami

16 S. Morawski, Bez „wampów” i cieplarnianych twarzy. Styl filmów radzieckich, „Echo Krakowa” 1948, nr 305 (954), s. 10.

17 S. Morawski, Dlaczego filmy radzieckie..., op. cit., s. 3. Turksib, reż. Wiktor Turin, prod. 1929, prem. 15 października 1929, ZSRR.

18 Ibidem. 
w filmie nieradzieckim, to przyjmował go aprobatywnie. Przykładem może być recenzja filmu Rzym, miasto otwarte ${ }^{19}$, którą rozpoczyna następująca deklaracja krytyka: „Wydaje się jednak, że najistotniejszym sprawdzianem wartości filmu jest to, w jakim stopniu wstrząsa widzem. Wstrząsa nie przez sensację czy dobrze zmontowaną niezwykłość, ale przez swą prawdę"20. W recenzowanym utworze na ten efekt składają się: znakomicie wyważona dramaturgia w pokazywaniu Niemców i członków włoskiego ruchu oporu; przekonujący bohater, który pokonuje oprawców postawą moralną; wyrastający z przebiegu akcji happy end, wyrażony zapowiedzią zwycięstwa nad faszystami; wyważone zniuansowanie negatywnych postaci; niewybielanie przeszłości, czyli nieunikanie odpowiedzialności za włoski faszyzm. Siłę wyrazu wzmocniły również środki wyrazu zapożyczone przez Rosselliniego z filmu dokumentalnego.

Inaczej ustosunkował się Morawski do filmu, w którym ważny społecznie temat nie znalazł w jego ocenie właściwego ujęcia, jak na przykład w Straconym weekendzie w reżyserii Billy'ego Wildera ${ }^{21}$. Przyczyn słabości filmu upatrywał w happy endzie wprowadzonym na zasadzie deus ex machina. Fabuła nie powinna kończyć się uzdrowieniem głównego bohatera, lecz jego samobójstwem lub hospitalizacją. Na dodatek reżyser uległ hollywoodzkiej manierze epatowania widza zdarzeniami ekstremalnymi. Kamera zdaniem Morawskiego niepotrzebnie przez długi czas pokazuje stany deliryczne alkoholika. Nie służy to celom wychowawczym, lecz podsyca jedynie niezdrowe zainteresowanie patologią. Wychowawczy wydźwięk utworu osłabiła również charakterystyka głównego bohatera, która wywołuje u widza uczucie sympatii dla niego. Konstrukcja tej postaci w żaden sposób nie powinna wywoływać chęci naśladownictwa. Podobnie w ramach polskiej kinematografii wyeksponowanie sensacji osłabiło wymowę filmu Skarb w reżyserii Leonarda Buczkowskiego ${ }^{22}$, w którym wprawdzie nie podjęto ważnego tematu, ale jako film rozrywkowy mógł zawierać satyryczną krytykę niepokojących zjawisk występujących wśród społeczności mieszkańców Warszawy, a może i innych miast polskich.

Spośród filmów polskich Morawski szczególnie chwalił dylogię w reżyserii Jerzego Kawalerowicza: Celuloza i Pod gwiazda frygijska ${ }^{23}$. Znalazł w niej postaci, a w szczególności postaci pierwszoplanowe, przemawiające prawdą psychologiczną.

19 Zob. S. Morawski, „Rzym, miasto otwarte”, „Gazeta Krakowska” 1949, nr 59, s. 6; Rzym, miasto otwarte (Roma, città aperta), reż. Roberto Rossellini, prod. 1945, prem. 25 września 1945, Włochy.

20 S. Morawski, ,Rzym, miasto otwarte”, op. cit., s. 6.

21 Zob. idem, ,,Stracony weekend”. Film produkcji amerykańskiej, „Gazeta Krakowska” 1949, nr 117, s. 6; Stracony weekend (The Lost Weekend), reż. Billy Wilder, prod. 1945, prem. 29 listopada 1945, USA.

22 Zob. S. Morawski, ,,Skarb”. Film produkcji polskiej, „Gazeta Krakowska” 1949, nr 16, s. 6; Skarb, reż. Marian Leonard [Leonard Buczkowski], prod. 1948, prem. 15 lutego 1949, Polska.

23 Zob. S. Morawski, „Celuloza”. Film produkcji polskiej, „Gazeta Krakowska” 1954, nr 109 (1738), s. 4; idem, ,,Pod gwiazda frygijska”,, „Gazeta Krakowska” 1954, nr 262 (1911), s. 4; Celuloza, reż. Jerzy Kawalerowicz, prod. 1953, prem. 27 kwietnia 1954, Polska; Pod gwiazda frygijska, reż. Jerzy Kawalerowicz, prod. 1954, prem. 30 października 1954, Polska. 
Zwrócił uwagę na umiejętnie pokazany proces kształtowania świadomości i charakteru Szczęsnego (Józef Nowak), delikatność w rysunku miłości między Szczęsnym i Madzią (Lucyna Winnicka), pogłębione psychologicznie postaci ojca Szczęsnego i Czerwiaczka (w obu rolach Stanisław Milski), Zofii Czerwiaczkowej (Teresa Szmigielówna) i szewca Łąpca (Kazimierz Opaliński). Morawski przekonywał,że reżyserowi udało się wydobyć prawdę o życiu w Polsce rządzonej przez sanację również poprzez znakomitą inscenizację. O jednej z najlepszych w tym względzie scen Celulozy pisał:

Przypomnijcie sobie ową scenę, w której delegacja robotników z Marusikiem przychodzi do grupy starego cieśli, żeby ich skłonić do wspólnego strajku i reakcję starego, zajadłą, ze łzami w oczach. To jest właśnie życie, surowe, powikłane, a przy tym takie proste, znane nam z osobistych widzeń i słyszeń, życie kunsztownie przetopione w wielką, porywającą prawdę artystyczną ${ }^{24}$.

W wątku miłosnym (Pod gwiazda frygijska) udało się reżyserowi nawiązać do tradycji romantycznej i subtelnego rysunku postaci, znanego z powieści Stefana Żeromskiego. Duże wrażenie na krytyku zrobiło również odtworzenie realiów życia codziennego w przedwojennej Polsce. Nie zgodził się z zarzutami braku spójności narracyjnej drugiej części dylogii. Stwierdził, że w jego odczuciu film nie jest złożony z „luźno związanych ze sobą epizodów epickich. (...) Rozwój Szczęsnego jest wyraźnie zaznaczony, a film w całości biorąc, właśnie uniknął pokawałkowania na oddzielne epizody" "25. Nietrafione zdaniem Morawskiego były również opinie, w których przypisywano dylogii Kawalerowicza wtórność wobec filmów włoskich, będącą rezultatem kopiowania stylu filmów neorealistycznych. W odpowiedzi domagał się wręcz pochwały dla reżysera za twórcze wykorzystanie najlepszych wzorów realistycznego kina.

\section{Dyskusja estetyków o rewaloryzacji pojęcia realizmu}

W drugiej połowie lat 50. i w pierwszej połowie lat 60 . XX wieku pojawiły się w kulturze zachodniej utwory i koncepcje, które zainicjowały dyskusję nad pojęciem realizmu. Krytycy i estetycy radzieccy wystąpili z licznymi publikacjami polemicznymi wobec zachodnich praktyk artystycznych i rozważań z zakresu historii sztuki oraz estetyki. W Polsce impulsem do przedyskutowania realizmu w sztuce były tezy zawarte w przemówieniu Władysława Gomułki wygłoszonym podczas XIII Plenum Komitetu Centralnego Polskiej Zjednoczonej Partii Robotniczej 4 lipca 1963 roku. Gomułka podkreślił, że partia nadal domaga się utworów realistycznych, pozostawiając jednocześnie w gestii artystów decyzje warsztatowe.

\footnotetext{
24 S. Morawski, ,Celuloza”..., op. cit., s. 4.

25 Idem, „Pod gwiazda frygijska”,..., op. cit., s. 4.
} 
Najważniejsze wysunięte przez radzieckich autorów tezy krótko zrelacjonowała czytelnikom „Ekranu” Regina Dreyer w połowie roku $1964^{26}$. Z przedstawionego przez nią opisu wynikało, że nie ma w ZSRR jednolitego stanowiska wobec realizmu w sztuce, nie wyłączając filmu. Wypowiedź Dreyer należała do cyklu artykułów poświęconych tematyce realizmu, które zamieszczano w „Ekranie” od połowy maja do połowy czerwca 1964 roku. Cykl ten rozpoczął artykuł Sława Krzemienia-Ojaka, w którym autor zaprezentował historyczne spojrzenie na realizm ${ }^{27}$. Alicja Helman scharakteryzowała poglądy André Bazina i Siegfrieda Kracauera ${ }^{28}$, a Jolanta Mach przybliżyła czytelnikom amerykański stosunek do realizmu ${ }^{29}$.

Stefan Morawski był autorem dwóch tekstów. W pierwszym przedstawił charakterystykę historycznie uporządkowanych marksistowskich definicji pojęcia realizmu ${ }^{30}$. W drugim przeprowadził krytyczną analizę tez zawartych w książce Rogera Garaudy'ego ${ }^{31}$ - francuskiego filozofa i do roku 1970 członka Francuskiej Partii Komunistycznej. Odniósł się również do stanowiska Bazina i Kracauera wobec realizmu filmowego. Podsumowując toczącą się ówcześnie w ZSRR dyskusję o realizmie, Morawski pisał: „I oto ujawnia się jakże aktualna i ostra polemika, którą marksiści wiodą między sobą. Chodzi mianowicie o to, czy realizm jako kategoria estetyczna wyznacza określone treściowo-formalne środki wyrazowe, czy też ich nie wyznacza"32. Rozwikłanie tego dylematu miało doprowadzić do uzgodnienia stosunku estetyków marksistowskich do sztuki awangardowej, ale można odnieść wrażenie, że Morawski z tego punktu widzenia ocenił również koncepcje realizmu Bazina i Kracauera. Zarzucił im bowiem weryzm wynikający z postulatu pozwolenia kamerze filmowej na rejestrację rzeczywistości, biegu zdarzeń przed obiektywem bez twórczej ingerencji artysty filmowca. Znaczyło to, że udział artysty, jego analizy rzeczywistości przestają być ważne dla filmu realistycznego. Jak wcześniej pisałem, Morawski podkreślał, jak ważne dla pokazania w filmie tego, co typowe (reprezentatywne dla danego czasu), jest poznanie i przeżycie rzeczywistości społecznej przez artystę. Bezrefleksyjne patrzenie na świat daje obraz powierzchowny.

Charakteryzując Bazinowską koncepcję realizmu, Alicja Helman przypomniała wątpliwości, jakie wysunął wobec niej Bolesław Michałek, dla którego nie do zaakceptowania był fakt, że ,(...) realizm przypisuje się środkom, a nie rezultatom działalności artystycznej, oraz teza o istnieniu koniecznych związków między realizmem

26 Zob. R. Dreyer, Za realizmem - przeciw schematom, „Ekran” 1964, nr 25 (376), s. 10.

27 Zob. S. Krzemień-Ojak, U źródet, „Ekran” 1964, nr 20 (371), s. 3.

28 Zob. A. Helman, Odbicie czy interpretacja, „Ekran” 1964, nr 26 (377), s. 11.

29 Zob. J. Mach, Sprawa treści, „Ekran” 1964, nr 24 (375), s. 11.

30 Zob. S. Morawski, O marksistowskim pojmowaniu realizmu, „Ekran” 1964, nr 21 (372), s. 10.

31 Zob. idem, Nowa czy stara formuła realizmu, „Ekran” 1964, nr 22 (373), s. 6-7, 10; R. Garaudy, D’un Réalisme sans rivages, Plon, Paris 1966.

32 S. Morawski, O marksistowskim pojmowaniu ..., op. cit., s. 10. 
środków wyrazowych a realizmem treści"33. Podobne kwestie zaniepokoiły Morawskiego. Trzeba jednak dodać parę zdań na temat koniecznych związków realizmu środków wyrazu filmowego z realizmem treści. Otóż dla Bazina ta konieczność związków polegała na przyczynowo-skutkowym związku filmowanych fizycznych obiektów z ich obrazem na taśmie filmowej. Przyczynowo-skutkową zależność zapewniały procesy fizyczne (odbicie światła) i procesy fizykochemiczne (obróbka filmu w laboratorium). W rezultacie zdaniem Bazina nie powstawał zwykły obraz, ale odcisk rzeczywistości - badacz pisał: „(...) istnienie obiektu sfotografowanego ma w sobie coś z istnienia modela, tak jak odcisk palca z palca"34. Taki odcisk rzeczywistości nie zachowuje jedynie jej wyglądów, lecz - jak pisała Helman - „(...) oferuje nam wielość sensów, objawia się w sposób ambiwalentny. I twórcy «wierzącemu w rzeczywistość» zależy właśnie na tym, by tę niejasność i wieloznaczność zachować, nie zastępując jej jednością sensu założoną przez artystę" ${ }^{35}$. Z marksistowskiego punktu widzenia wieloznaczność filmu musi być co najmniej niepokojąca, ponieważ blokuje jego funkcję wychowawczą. Znaczy to, że nie mobilizuje do zmian społecznych.

Zarzut powierzchownego patrzenia na rzeczywistość należy również oddalić w stosunku do koncepcji filmowego przedstawiania materialnej rzeczywistości Siegfrieda Kracauera. Za najbardziej realistyczne uznał Kracauer filmy oparte na „wątku znalezionym"36. Wątek znaleziony to odkryty przez filmowca wzór rzeczywistości. Niemarksistowskie jest odkrywanie go przez obserwację zamiast przez marksistowską analizę procesu dziejowego.

W dyskusji na temat istnienia właściwych realizmowi środków wyrazu Morawski przyjął stanowisko ewolucyjne. Zgodnie z wcześniej wyrażonym poglądem, że nie ma jednego wzoru realistycznego dzieła sztuki, lecz realizm zmienia się wraz ze zmianami społeczno-ekonomicznymi, był skłonny zróżnicować typy realizmu. Odnosząc się do filmów Federica Felliniego i Michelangela Antonioniego, w których przestawiona jest rzeczywistość subiektywna, stwierdził: „Marksista zgodzi się więc na rozszerzenie formuły realizmu tak, by objęła [ona] głęboko przeżyty przez artystę przekaz alienacji społecznej, ale będzie chyba rozróżniał między realizmem a realizmem, i będzie je hierarchizował" 37 .

33 A. Helman, André Bazin [w:] A. Helman, J. Ostaszewski, Historia myśli filmowej. Podręcznik, Słowo/ Obraz Terytoria, Gdańsk 2007, s. 158.

34 A. Bazin, Film i rzeczywistość, przeł. B. Michałek, Wydawnictwa Artystyczne i Filmowe, Warszawa 1963, s. 16.

35 A. Helman, André Bazin, op. cit., s. 156.

36 S. Kracauer, Teoria filmu. Wyzwolenie materialnej rzeczywistości, przeł. W. Wertenstein, Wydawnictwa Artystyczne i Filmowe, Warszawa 1975, s. 266.

37 S. Morawski, Nowa czy stara formuła ..., op. cit., s. 10. 


\section{Krytyk wobec ewolucji filmu realistycznego}

Film Słodkie życie ${ }^{38}$ zdaniem Morawskiego był przykładem „realizmu naszej doby" ${ }^{39}$. W recenzji krytyk zawarł krótką jego interpretację. Na wstępie zwrócił uwagę, że ,jeśli styl rozumieć jako zespół swoistych elementów treściowo-formalnych, to można by wyróżnić jego rozmaite, coraz szersze kręgi: od indywidualnego przez klasowy i narodowy do ponadnarodowego" ${ }^{40}$. W kręgu ponadnarodowym, według Morawskiego, Fellini zestawił metafory dotyczące dwóch postaw życiowych: zachodnią - nastwioną na używanie życia, na przyjemność cielesną, skonfrontował z postawą wschodnią - wyrażającą się poprzez kontemplację, poszukującą wartości duchowych. Krąg narodowy objął symbolikę katolicką, a konkretnie jej włoską wersję. W kręgu klasowym Fellini umieścił przedstawicieli rzymskiej elity towarzyskiej. Wreszcie w kręgu indywidualnym znajduje się sam reżyser. Morawski w swojej interpretacji pokazał, jak artystyczna wrażliwość Felliniego wyrasta z warunków społeczno-kulturowych, w których tworzy, oraz w jaki sposób Fellini przetwarza otaczające go symbole i mity. W rezultacie film Słodkie życie bardziej prezentuje rozterki intelektualne i emocjonalne reżysera niż obraz rzeczywistego życia pewnej grupy mieszkańców Rzymu. Konkludując, Morawski zaznacza, że konstrukcja filmu jest pułapką, która zamyka drogę do jasnego i pozytywnego przesłania. Pisał:

Wyszedłem z kręgu najszerszego, by dojść do osobowości twórczej Felliniego: właściwsza jednak byłaby odwrotna droga. Mimo bowiem narzucającego się mniemania, iż wyróżnione kręgi jak obręcze zamykają jedne drugie, wszystkie z nich zachodzą na siebie i wszystkie z nich dadzą się wywieść z fundamentalnych właściwości stylu Felliniego ${ }^{41}$.

W rezultacie tego przenikania indywidualnych środków wyrazu z symboliką kulturową uwaga widza zostaje zatrzymana na wątpliwościach reżysera wobec otaczających go zjawisk społecznych i kulturowych, zamiast oferować widzowi pozytywną na nie odpowiedź. Morawski docenił moralizatorski ton w filmie Felliniego, ale sugestię, że odrodzenie ludzkości może przynieść miłość, uznał za skrajnie naiwną. Należy zresztą dodać, że Fellini nie wskazuje miłości jako drogi wybawienia dla upadającej cywilizacji, ale jedynie podsuwa widzowi pytanie o jej odradzającą moc.

W podpisanej pseudonimem Marek Stefanowicz recenzji filmu Trapez wyreżyserowanego przez Carola Reeda Morawski zwrócił uwagę na amerykańską wersję realizmu filmowego: „Film amerykański lat powojennych był dla nas wielkim odkryciem. Poznaliśmy go od najlepszej strony - jako szkołę realistyczną z niezwykłym wyczuciem artystycznej swoistości kina. Banałem jest powtarzać dzisiaj, iż

38 Stodkie życie (La dolce vita), reż. Federico Fellini, prod. 1960, prem. 3 lutego 1960, Włochy.

39 S. Morawski, Nowa czy stara formuła ..., op. cit., s. 10.

40 Idem, Styl Felliniego, „Ekran”, nr 35 (386), s. 6.

${ }^{41}$ Ibidem, s. 7. 
amerykański «x» czy «y» zawiera sporo prawdy środowiskowej” ${ }^{2}$. Za szczególnie wartościowe uznał rysunek środowiska cyrkowców, który daje nasycone prawdziwymi zachowaniami tło dla rozterek moralnych głównego bohatera; świetnie poprowadzoną linię dramaturgiczną, która precyzyjnie buduje emocje widza; doskonałe wcielenie się w rolę przez Burta Lancastera.

Dokonujące się zmiany w sztuce filmowej odnotował Stefan Morawski w miarę jak wyrażające je filmy pojawiały się na polskich ekranach. Relacjonując w połowie stycznia roku 1960 swoje wrażenia z III Festiwalu Festiwali Filmowych, zwrócił uwagę, że w filmie światowym rozwinęła się tendencja do filmu filozofującego. Zdaniem Morawskiego coraz częściej w ówczesnych filmach podejmuje się próby syntezy egzystencji człowieka. Do tych syntez reżyserzy przybliżają się, zadając pytania. W sztuce artykułuje się pytania, używając środków wyrazu. Jednak, gdy pytanie jest błahe, łatwo przecenić zabieg formalny, którym zostało obudowane. Na ogół reżyserzy poprzestają na zadaniu pytania, ale zdarzają się filmy oferujące widzom odpowiedzi. Najwartościowsze z nich są te, które dają odpowiedzi nowe. Filozofując, film uzupełnia filozofię i naukę. Ze względu zaś na rangę artystyczną najlepszych filmów przełomu lat 50. i 60. XX wieku stało się jasne, że sztuka „(...) (a wśród niej chyba najbardziej za naszych dni - film) jest nie tylko królestwem form, jest także (i chyba przede wszystkim) sumieniem ludzkości"43. Trzy lata później Morawski po zapoznaniu się z filmami wypełniającymi program kolejnego Festiwalu Festiwali Filmowych - bronił tezy o oscylowaniu sztuki filmowej pomiędzy weryzmem a intelektualizmem ${ }^{44}$. Opisując obawy niektórych krytyków, estetyk i krytyk jednocześnie wyjaśnił, że sztuce filmowej z jednej strony grozi rozmycie w samej rzeczywistości, w samym życiu, a z drugiej wchłonięcie przez filozofię. Nurt cinéma-vérité stał się zapowiedzią utożsamienia filmu z rzeczywistością i odwrotnie. Morawski nie wsparł tej tezy, twierdząc, że w sztuce i w sztuce filmowej również nie ma wypierania starych dzieł przez nowe, lecz jest ich koegzystencja. Oscylacja filmu pomiędzy weryzmem a intelektualizmem w przekonaniu Morawskiego świadczy o niepewności, czy sztuka wciąż potrafi zadawać najważniejsze dla człowieka pytania i proponować odpowiedzi.

\section{Estetyk ocenia stronę etyczną filmów}

Wrażliwość na aspekt etyczny filmu ujawnił Morawski już we wczesnych recenzjach. Chociaż początkowo najmocniej akcentował wagę zawartej w filmie prawdy życiowej, nie zapominał o skomentowaniu wyrażonej w nim oceny moralnej. Zdarzało się, że pisząc o filmie, którego fabuła opierała się na rzeczywistych zdarzeniach, Morawski na plan pierwszy wysuwał etyczny wydźwięk jego przesłania. Takim filmem był

42 M. Stefanowicz [Stefan Morawski], Trapez, czyli idée fixe, „Ekran” 1959, nr 33 (123), s. 11; Trapez (Trapeze), reż. Carol Reed, prod. 1956, prem. 30 maja 1956, USA.

43 S. Morawski, Pytania, formy, odpowiedzi, „Ekran” 1960, nr 2 (144), s. 7.

44 Zob. S. Morawski, O niepokojach XX-wiecznych i tzw. końcu sztuki, „Ekran” 1963, nr 9 (308), s. 7. 
Rzym, godzina 11 w reżyserii Giuseppe De Santisa ${ }^{45}$. Inspirację dla scenariusza stanowił wypadek. W roku 1951 w jednej z rzymskich kamienic, niewyremontowanej od zakończenia wojny, załamały się schody, na których znajdował się tłum bezrobotnych kobiet. Oczekiwały one na rozmowę kwalifikacyjną do pracy w charakterze maszynistki. Czytelnik znający już postawę krytyczną Morawskiego mógł się spodziewać, że w recenzji znajdzie porównanie akcji filmu do życia codziennego w Rzymie na początku lat 50. XX wieku. Krytyk natomiast zajął się indywidualnymi i społecznymi konfliktami na płaszczyźnie moralnej. Opisał, w jaki sposób udało się twórcom filmu połączyć je w skierowany do widza apel przeciwko niesprawiedliwości społecznej:

[Rzym, godzina 11 - przyp. J.Z.] jest filmem chwytającym za gardło, wstrząsającym. Skondensowana jest w nim cała seria dotychczasowych filmów włoskich o bezrobociu. (...) Wrażliwy i myślący człowiek przeżywszy go musi sobie powiedzieć, że takiego świata, jaki przedstawia Rzym, godzina 11 tolerować nie można i nie wolno. Dlatego też film ten jest głęboko ludzki ${ }^{46}$.

Wraz ze zmianami w sztuce filmowej Morawski coraz częściej wysuwał aspekt etyczny utworu na pierwszy plan. Przykłady najłatwiej znaleźć wśród filmów wojennych. A konkretnie w tych, w których dramaturgia opierała się na konflikcie obowiązku z sumieniem. W recenzji filmu Rozkaz: zabic ${ }^{47}$, którego reżyserem był Anthony Asquith, Morawski (ps. Helena Opoczyńska) wydobywa z utworu ważne pytania:

Czy pilot zrzucający bomby na ludność cywilną, w większości wypadków na ludzi niewinnych - jest bohaterem, czy po prostu zbrodniarzem? Dlaczego poczucie winy rośnie u niego odwrotnie proporcjonalnie do fizycznej odległości od swej ofiary? Czy „technologia” mordu z punktu widzenia moralnego może stanowić jakąkolwiek różnicę? Pytanie następne: gdyby rozkaz zabicia zdrajcy wydano nie wrażliwemu chłopcu, a zgodnie z pierwotnymi planami kierownictwa wywiadu - wprawionemu w „mokrej robocie” zbójowi - czy wtedy przestałby również istnieć sam problem? I odwrotnie - czy człowiek, jeśli chce być godnym tego miana, rozprawiając się nawet z rzeczywistym zdrajcą w sposób ukazany przez Asquitha, ma prawo obmyć ręce - a również pamięć - ze śladów krwi? Gdzie właściwie przebiega granica między morderstwem a posłuszeństwem wobec wojennych rozkazów? Wreszcie - jaki jest stosunek odpowiedzialności moralnej jednostki, wykonującej rozkazy, do odpowiedzialności tych, którzy je wydają? ${ }^{48}$

W zakończeniu recenzji Morawski przyznaje, że na te pytania nie ma odpowiedzi w filmie i poza nim. Liczy się jednak efekt poruszenia widza do ich przemyślenia. Aby uzmysłowić osobom, które nie przeżyły wojny, czym ona jest, należy zastąpić epikę wojenną wewnętrznym dramatem moralnym.

45 Zob. Rzym, godzina 11 (Roma, ore undici), reż. Giuseppe De Santis, prod. 1952, prem. 28 grudnia 1952, Włochy.

46 S. Morawski, ,,Rzym, godzina 11”. Film produkcji włoskiej, „Gazeta Krakowska” 1954, nr 31 (1680), s. 4.

47 Zob. H. Opoczyńska [S. Morawski], Przykazanie a rozkaz, „Ekran” 1960, nr 13 (155), s. 6; Rozkaz: zabić (Orders to Kill), reż. Anthony Asquith, prod. 1958, prem. 13 kwietnia 1958, Wielka Brytania.

48 Ibidem, s. 6 . 
Po wielu latach od napisania tej recenzji w artykule poświęconym dewastacji człowieczeństwa przez cyfrową technologię Morawski pisał:

Dla mnie - być może ze względu na formację pokoleniową - sztuka jest przede wszystkim kwestią etosu, jej głównym zdaniem jest odmowa przyjęcia rzeczywistości zastanej, wskazanie, że może być inaczej, usiłowanie transgresji świata, hic et nunc, samozrozumienia siebie w relacji do Innych, do bytu, który trwa niedoceniony ${ }^{49}$.

Argumentował, że technologia niszczy człowieczeństwo, ponieważ zdejmuje z człowieka samą potrzebę podejmowania odpowiedzialności za własne decyzje. Technologia multiplikuje wyglądy, uprzedmiotawia człowieka wraz z jego cielesnością, włączając wytworzone obrazy w niekończący się łańcuch obrazów, których rola wyczerpuje się w - jak pisał Marshall McLuhan - masowaniu zmysłów widza. A przecież, zapewnił Morawski, człowiek nie może obyć się bez ustosunkowania etycznego do otaczającej go rzeczywistości - również tej medialnej.

Muszę jeszcze zaznaczyć, że aspekt etyczny filmu był dla Morawskiego decydujący w ocenie filmów rozrywkowych i rysunkowych animacji. W tych filmach, którym nie sposób było stawiać zarzut rozmijania się z prawdą życiową, skupiał ostrze oceny na ich wpływie na odbiorcę. Doskonale rozumiał, że podlegają one regułom gatunku i prezentują widzowi fikcję. Odrzucał te z nich, w których nie znajdował zachęty do przemyśleń etycznych. Jednym z przykładów jest recenzja filmu Złoty kask $^{50} \mathrm{w}$ reżyserii Jacques'a Beckera, w której analizę melodramatycznej akcji Morawski podsumował następująco:

Dobra sztuka zawsze stwarza własny świat z własnymi prawami i narzuca go czytelnikowi lub widzowi. Fikcja ta może być na tyle silna, że wyłącza normalne reakcje moralne; i dobrze jest, jeśli zmusi nas do gruntownego przemyślenia tych potocznych zasad, które wydają się oczywiste, a oczywistymi wcale nie są ${ }^{51}$.

W rysunkowych filmach animowanych Morawski koncentrował uwagę na etycznym aspekcie przesłania i wrażeniach estetycznych wywołanych środkami wyrazu: kolorem, ruchem, kształtami, kompozycją obrazów. Podkreślał, że niezmiernie ważne jest emocjonalne oddziaływanie na widza, na ogół dziecięcego, ponieważ otwiera drogę do przyjęcia treści dydaktycznych. W latach 50. XX wieku wartości te odnajdował w wybranych animacjach radzieckich ${ }^{52}$, ale odpowiadając na ankietę przepro-

49 S. Morawski, Kino etosu czy akcji, „Kwartalnik Filmowy” 2000, nr 29-30 (89-90), s. 5.

50 Idem, Liryczna miłość wśród apaszów, „Polityka” 1958, nr 19 (63), s. 8; Złoty kask (Casque d’or), reż. Jacques Becker, prod. 1952, prem. 13 marca 1952, Francja.

51 Ibidem, s. 8 .

52 Zob. S. Morawski, Kreskówki radzieckie, „Gazeta Krakowska” 1950, nr 101 (416), s. 8; idem, Kreskówki, „Gazeta Krakowska” 1954, nr 227 (1876), s. 4. 
wadzoną przez redakcję „Kwartalnika Filmowego” w roku 1993, umieścił Fantazję $e^{53}$ Disneya wśród dwudziestu najbardziej cenionych przez siebie filmów.

Należy jeszcze poświęcić kilka zdań opisowi trybu, w jakim Morawski odbierał film. W recenzji filmu Rififi w reżyserii Jules’a Dassina Morawski podał swoją odpowiedź na pytanie, dlaczego kino ,jest sztuką najbliższą memu pokoleniu? (...) Kino jest drugim życiem i tak samo jak to życie zawiera wszelkie możliwości" ${ }^{54}$. Następnie Morawski wyznał, że szczególnie silnie intryguje go pytanie, dlaczego racje postaci, które łamią niektóre normy społeczne (na przykład prawne), są dla widza przekonujące. W odpowiedzi wyjaśnił, że dzieje się tak w dużym stopniu z powodu solidaryzowania się widza $\mathrm{z}$ tymi postaciami:

Jeśli jakąś grupę społeczną pokazujemy niejako „od wewnątrz” (a szczególnie w jej wewnętrznych konfliktach, gdzie role dobre i złe są wyraźnie podzielone), jesteśmy skłonni przyjąć racje etyczne przedstawionych pozytywnie bohaterów. Pomijamy wtedy prawo urzędowe, jubilera i jego stratę; pozostaje tylko szlachetny Toni, który ratuje malca przed łajdakami z drugiej bandy ${ }^{55}$.

Moim zdaniem w tych wyjaśnieniach Morawskiego znajduje się istotna wskazówka, jak rozumieć jego postawę estetyczną wobec filmu. Aby rozszyfrować tę wskazówkę, muszę przywołać pojęcie identyfikacji. Prawdopodobnie pierwszy opisał je Béla Balázs jako zjawisko percepcyjnego utożsamiania się widza również ze spojrzeniem kamery: „siedząc w kinie, czujemy, jak kamera filmowa porywa nasz wzrok, zmuszając nas do zajęcia się akcją filmu. Patrząc na przestrzeń obrazu filmowego, odnosimy wrażenie, że znajdujemy się wewnątrz klatki filmowej otoczeni postaciami filmu" ${ }^{56}$. Otóż Morawski identyfikuje się z postaciami, ale decydującym czynnikiem w tym akcie psychicznym jest podobieństwo postaw etycznych. Moim zdaniem, używając wyrażenia: ,pokazujemy niejako «od wewnątrz»»", Morawski nie ma na myśli percepcyjnego wrażenia przebywania widza wśród gangsterów, ale to, że widz poznaje motywacje ich działania, ich myśli i emocje. W odbiorze tego filmu percepcja zmysłowa została podporządkowana postawie etycznej. W dalszej części omawianej recenzji Morawski wyjaśnia, że gdyby podział na dobrych i złych nastąpił wśród pokazanych na ekranie hitlerowców, o których wiadomo, że w trakcie akcji filmu mordowali cywilów, to odczułby do nich odrazę. Utożsamienie z „dobrym” gangsterem jest możliwe dlatego, że jest on - jak pisze Morawski - wydziedziczony, czyli wyrwany z kontekstu doświadczenia życiowego autora recenzji.

53 Zob. idem, 20 najlepszych. Ankieta (3), „Kwartalnik Filmowy” 1993, nr 3 (63), s. 213; Fantazja (Fantasia), reż. James Algar, Samuel Armstrong, Ford Beebe Jr., Norm Ferguson, David Hand, Jim Handley, Thornton Hee, Wilfred Jackson, Hamilton Luske, Bill Roberts, Paul Satterfield, Ben Sharpsteen, prod. 1940, prem. 19 września 1941, USA.

54 M. Stefanowicz [S. Morawski], Różne różności i , Riffif”, „Ekran” 1959, nr 28 (118), s. 15; Rififi (Du rififi chez les hommes), reż. Jules Dassin, prod. 1955, prem. 13 kwietnia 1955, Francja.

55 Ibidem.

56 B. Balázs, Wybór pism, przeł. R. Porges, K. Jung, Filmowa Agencja Wydawnicza, Warszawa 1957, s. 63. 


\section{Rozważania metakryłyczne estetyka}

W sprawie krytyki filmowej, zasad pisania recenzji i typów postaw krytycznych Stefan Morawski zabierał głos wielokrotnie. W najpełniejszej formie swoje poglądy przedstawił w artykule $U$ podstaw krytyki filmowej ${ }^{57}$. Rozpoczął go od postawienia tezy o koniecznym związku krytyki z estetyką. Obie te dziedziny łączy aksjologia, obie zajmują się wartościami. Estetyka wyjaśnia, czym jest wartość estetyczna, a krytyka wspiera estetykę, gromadząc materiał do badań. Estetyka przygotowuje i proponuje krytyce cały zestaw narzędzi i metod opracowywania artefaktów kultury pod kątem ich wartości estetycznych. Morawski pisał: „Estetyka ponadto wyjaśnia, że ustalenie wartości możliwe jest na różne sposoby: np. obiektywistyczny, subiektywistyczny, relacjonistyczny, czyli wartość estetyczną wskazuje się w samym dziele albo w przeżyciu estetycznym, albo na styku jednego i drugiego" ${ }^{58}$. Estetyk w badaniach może wspierać się zarówno tezami filozoficznymi, jak i ustaleniami nauk szczegółowych: psychologii, socjologii czy historii kultury. W pespektywie estetycznej cenne w danym artefakcie kultury - Morawski pisał o dziele sztuki - mogą być albo jedynie wartości formalne, albo formalne i treściowe. Wartości estetycznych można szukać wyłącznie w obrębie samego artefaktu lub w jego zgodności z rzeczywistością poza nim.

Morawski rozróżnił dwa typy uprawiania krytyki: analityczny i nieanalityczny. Typ analityczny wykorzystuje w różnym stopniu precyzji naukowy aparat pojęciowy. W typie nieanalitycznym można oddzielić dwa subtypy krytyki: kreacyjny oraz filozoficzno-literacki i postulatywny. Morawski wyjaśnił, że zdecydował się na podział dychotomiczny, ,ponieważ krytyka postulatywna jest w pewnym sensie również charakteru ekspresyjnego" ${ }^{59}$. Kryterium podziału tych subtypów stanowi proporcja udziałów wizji świata artysty i krytyka. Gdy krytyk całkowicie podąża za wizją artysty, to realizuje krytykę kreacyjną, gdy dzieło jest inspiracją do rozwinięcia przez krytyka własnej wizji, to jest to krytyka filozoficzno-literacka. W przypadku połączenia wizji artysty z wizją krytyka powstaje subtyp postulatywnej krytyki. Morawski zaznaczył, że wymienione typy i subtypy są jedynie punktami orientacyjnymi w przestrzeni różnorodnych sposobów uprawiania krytyki i nie wyczerpują jej wszystkich form.

Dwa główne typy krytyki pełnią swoiste funkcje. Krytyka analityczna jest nastawiona na eksplikację, którą realizuje poprzez „opis, wyjaśnienie i ocenę wynikającą z procesu wyjaśnienia danego fenomenu artystycznego" ${ }^{\circ 0}$. Nieanalityczny typ krytyki może pełnić dwie funkcje: kreacyjno-ekspresyjną i postulatywną ${ }^{61}$. W funkcji kreacyjno-ekspresyjnej krytyk, wypowiadając się o utworze, wyraża swój stosunek

57 S. Morawski, U podstaw krytyki filmowej, „Kwartalnik Filmowy” 1963, nr 1-2 (49-50).

58 Ibidem, s. 12.

59 Ibidem, s. 18.

60 Ibidem, s. 16.

61 Ibidem. 
do świata. Jego wypowiedź jest silnie nacechowana wyrażeniem własnego doświadczenia. Realizując funkcję postulatywną, krytyk nie wyraża własnej wizji świata ani osobistych przeżyć, lecz stawia przed twórcą żądania, „by spełnione zostały wartości takie to a takie, twórcy dalekie lub obce, krytykowi zaś najbliższe"62. W obrębie tych dwóch funkcji krytycy odgrywają dwie różne role. W funkcji eksplikacyjnej krytyk pośredniczy w obiegu dzieł, w funkcji kreacyjno-ekspresyjnej krytyk zajmuje miejsce artysty nawiązującego nić porozumienia z odbiorcami. Obie funkcje łączy intencja interwencyjna ${ }^{63}$. Eksplikacja ma ułatwić zrozumienie dzieła lub przekonać do niego. Funkcja postulatywna zaś zmierza do narzucenia wartości uznawanych przez krytyka zarówno twórcom, jak i odbiorcom.

Typ analityczny zdaniem Morawskiego może zostać podzielony na cztery postacie w zależności od przedmiotu refleksji krytycznej. Pierwsza postać dotyczy

(...) wartości formalno-strukturalnych, II - wartości mimetycznych, zawartych w globalnej strukturze utworu (przy czym zarówno w I, jak i w II występują wartości ekspresyjne, będące wyrazem stosunku danego artysty do rzeczywistości), III - pola genetycznego, z którego utwór można wywieść, IV - pola funkcjonalnego, tzn. jego recepcji w danym momencie historycznym (lub w momentach późniejszych ${ }^{64}$.

Głównym obszarem aktywności krytyka analitycznego są przedmioty wymienione w punktach pierwszym i drugim. Rozważania dotyczące genezy utworu wyprowadzają analityka ku naukom szczegółowym, jak na przykład psychologii, socjologii. Podejmując ten kierunek, krytyk zmierza do wyjaśnienia uwarunkowań psychologicznych lub socjologicznych, które wpłynęły na ukształtowanie sylwetki twórczej artysty i proces twórczy. Zwrócenie się przez krytyka w stronę recepcji dzieła stawia sobie za cel wyjaśnienie reakcji widzów. Wymaga ono analizy czynników socjologicznych, ekonomicznych, politycznych.

Przechodząc do subtypu kreacyjno-ekspresyjnego krytyki nieanalitycznej, Morawski pisał, że

(...) występuje w postaci: I - impresyjnej, tzn. rozważań fragmentarycznych na różne tematy stymulowane przez dzieło lub też pozaartystyczne zjawiska, II - psycho-biografizującej, tzn. portretów artystycznych, których zaledwie marginesem są same dzieła. (...) III - filozoficznej, tzn. prezentowania określonej wizji rzeczywistości, w ramach której wartości artystyczne odgrywają mniej lub więcej doniosłą rolę ${ }^{65}$.

Z kolei subtyp postulatywny wykorzystuje systemy norm wypracowane w obrębie etyki, religii, poetyki (np. podręcznik Horacego), doktryn społeczno-politycznych lub akademickiego kanonu sztuki. Cechą wspólną tych postaci krytyki postulatywnej jest absolutyzacja wybranego porządku aksjologicznego.

\footnotetext{
62 Ibidem.

63 Ibidem.

64 Ibidem, s. 17.

65 Ibidem, s. 18.
} 
Morawski zarysował również związki wymienionych na początku stanowisk estetycznych z typami krytyki ${ }^{66}$. Stanowisko subiektywistyczne jest podłożem krytyki impresyjnej lub opisującej psycho-biograficzną genezę utworu. Obiektywistyczne stanowisko na ogół przejawia się w krytyce analitycznej lub w filozoficznej postaci subtypu kreacyjno-ekspresyjnego albo w zapożyczaniu religijnych norm dla krytyki postulatywnej. Obiektywistyczne nastawienie ujawnia się w traktowaniu dzieł, wartości estetycznych lub norm jako przedmiotów niezależnych od ludzkiej percepcji i intelektu. Stanowisko relacjonistyczne wykazują często te postacie krytyki, które posiłkują się naukami szczegółowymi. Istotnym uzupełnieniem opisu tych związków jest podkreślenie przez Morawskiego znaczenia smaku estetycznego i światopoglądu krytyka ${ }^{67}$. Światopogląd jest prymarny wobec wszystkich przeprowadzonych przez krytyka wyborów i determinuje je w decydującym stopniu. Dlatego krytyk powinien dążyć do samoświadomości w tym zakresie, a także ujawnienia go czytelnikom swoich recenzji. Smak estetyczny jest pojęciem trudnym, prawie nieuchwytnym w refleksji metakrytycznej, a jednocześnie niezbędnym do uprawiania krytyki filmowej. Niestety dla niektórych potencjalnych i obecnych krytyków smak można kształtować jedynie w pewnym zakresie - jak podkreślił Morawski - „dobrego smaku można się jeszcze nauczyć, ale smak trzeba po prostu mieć" ${ }^{68}$.

Komentując zaprezentowaną typologię sposobów uprawiania krytyki artystycznej, Morawski wyraził pogląd na temat jej hierarchicznego uporządkowania. Podkreślił, że nie ma powodów do wskazywania lepszych i gorszych typów krytyki. Każdy typ lub postać subtypu jest równie dobra w obcowaniu z dziełem sztuki i propagowaniu jego wartości. Dodał jednak, że ,z estetycznego punktu widzenia, a ten w przypadku krytyki artystycznej musi być rozstrzygający, wartości strukturalne (immanentne) wysuwają się na czoło. Jeśli zatem krytyk nie dokonuje interpretacji, jeśli ocenia niejako z zewnątrz, to działalność jego nie jest w pełni autentyczna" ${ }^{69}$.

Morawski wielokrotnie od początku publikowania swoich rozważań metakrytycznych postulował, a właściwie domagał się, aby krytycy konstruowali swoje oceny, nie pomijając analizy warsztatowej utworu. Uważał, że każdy krytyk powinien obowiązkowo przyjrzeć się pracy ekipy filmowej podczas produkcji filmu ${ }^{70}$. Śledził na bieżąco recenzje ukazujące się w prasie i na poparcie swoich słów o powierzchowności sądów recenzenta przywoływał konkretne przykłady. Zwracał uwagę, że w istocie treścią wielu recenzji jest opis pozafilmowych elementów utworu. Wiele recenzji jego zdaniem realizowało prosty szablon, złożony z trzech punktów ${ }^{71}$. Pierwszym jest opis treści filmu. Drugim - na ogół najobszerniej potraktowanym - są rozważania na temat problematyki filmu. Trzeci punkt zawiera kilka spostrzeżeń dotyczących

66 Zob. ibidem, s. 20.

67 Ibidem, s. 25.

68 Ibidem.

69 Ibidem, s. 23.

70 S. Morawski, Uwagi o krytyce filmowej, „Kwartalnik Filmowy” 1951, nr 3-4, s. 12-13.

71 Zob. idem, O krytyce filmowej w piśmie..., op. cit., s. 4. 
rezultatów pracy niektórych członków ekipy filmowej: aktorów, reżysera, operatora, kompozytora, a czasami scenografa. Dopiero ten trzeci punkt odnosi się do środków wyrazu filmowego, a jest on często zmarginalizowany. Punkty pierwszy i drugi odsyłają do wartości pozafilmowych. Opis treści, jeśli jest rzetelny, wydobywa wartości scenariusza, czyli literackiej podstawy filmu. Analiza i komentarz do problemowego aspektu filmu wyprowadzają recenzenta i czytelnika w stronę różnych systemów normatywnych, nauk szczegółowych i indywidualnego światopoglądu ich autora.

Morawski miał również precyzyjne wyobrażenie, jak powinna wyglądać doskonała recenzja filmowa:

Recenzja powinna być pisana tak, by dopowiadała (a nie opowiadała), czego uczy bohater filmu i jego losy. Recenzja nie może jednak poprzestać na odszyfrowaniu ideologicznego alfabetu filmu, musi powiedzieć także o tym, dlaczego film wzrusza, co i dzięki czemu jest w nim żywe, przekonujące, czy jego dramaturgia, aktorskie kreacje, zdjęcia, podkład muzyczny, montaż przemówiły do naszej wyobraźni ${ }^{72}$.

Morawski sprzeciwiał się krytyce nastawionej na promowanie wybranego filmu ze względu na kontekst polityczny, społeczny lub ekonomiczny. To zadanie należy do obowiązków polityka kulturalnego. Odrzucił również krytykę, która nie uwzględnia zmienności form artystycznych i stawia się w roli strażnika jednego jedynego prawidłowego kanonu estetycznego. W zakończeniu swoich rozważań Morawski przestrzegał przed traktowaniem zaprezentowanej typologii jako jedynej i ostatecznej wykładni mechanizmów krytycznych. Silnie pokreślił, że tak jak krytyk musi liczyć się ze zmiennością sztuki, tak metakrytyk musi uwzględnić dynamiczną praktykę refleksji nad nią.

Podsumowując, analiza recenzji filmowych Stefana Morawskiego ujawnia, że jego postawa estetyczna ewoluowała wraz ze zmianami filmu. W procesie tym jako estetyk towarzyszył ewolucji pojęcia realizm, a jako krytyk prowadził nieustanną konfrontację postawy estetycznej i etycznej. Rodzące się z tej konfrontacji pytania egzystencjalne zadawał ocenianym przez siebie filmom. Odkrywając mechanizmy kształtujące krytykę filmową, Morawski deklarował, że rozumie nieuchronny proces ewolucji własnych poglądów. Szczególną wagę przywiązywał do opierania oceny dzieła filmowego na analizie związku znaczeń filmu z jego środkami wyrazu. Za najcenniejsze uważał filmy, które podejmują poważny temat, bez uproszczeń i korzystania ze schematów i dzięki doskonałej przyległości formy i treści mobilizują widza do naprawiania świata.

Kończąc, chciałbym jeszcze odnieść się do dwóch kwestii. Pierwsza dotyczy działalności krytycznej Stefana Morawskiego w kontekście polityczno-ideologicznym. Druga - znaczenia krytyki filmowej w kontekście jego poglądów filozoficznych. Będzie to jedynie kilka uwag, które mają uzupełnić przestawiony powyżej obraz refleksji Morawskiego o filmach i krytyce. Obie dotykają spraw złożonych

72 Ibidem. 
i wymagających wielopoziomowego, pozwalającego na subtelne rozróżnienia opisu. Każda z nich mogłaby stanowić temat odrębnej rozprawy. Siłą rzeczy więc przedstawiony przeze mnie w tym miejscu szkic nie wyczerpie tematu i nie da pogłębionych wniosków. Nie mogę jednak z tego skromnego uzupełnienia zrezygnować, gdyż wyrwanie krytycznej i metakrytycznej aktywności Morawskiego z obu wymienionych kontekstów sugeruje, że ewolucja jego poglądów dobywała się wyłącznie w rezultacie przemyśleń na temat filmu.

Wpływu polityki na krytyka, w tym również krytyka filmowego, w całym okresie PRL-u nie trzeba udowadniać. Był on przemożny i realizowany różnymi drogami. Przede wszystkim, jak oceniała Helman ${ }^{73}$, krytyk musiał realizować dyrektywy polityki kulturalnej. I była to najłagodniejsza z form nacisku. Mocniejsze środki przymusu nakładano metodami administracyjnymi za pośrednictwem redaktorów naczelnych i cenzorów. Ta forma represjonowania wypowiedzi dotykała również recenzje Morawskiego i jego samego. Napisał o tym wprost w cytowanym już przeze mnie artykule o działalności krytyka w prasie codziennej. Wprawdzie zapewnia w nim, że pisząc dla „Gazety Krakowskiej”, miał dobre warunki pracy, co wyrażało się gotowością zarówno redaktora naczelnego, jak i innych członków zespołu do dyskusji o dostarczanych recenzjach. Można się domyślać, że w innych redakcjach decyzje o odrzuceniu recenzji były podejmowane arbitralnie. Odwołując się do własnych doświadczeń, Morawski przywołuje kilka przykładów:

Przez długi czas nie drukowano recenzji z filmów radzieckich, jeśli zwracałem uwagę na ich niedostatki. (...) Odrzucono kiedyś recenzję filmu Feliks Dzierżyński, gdyż ostro skrytykowałem błędy scenariusza. (...) Do tej listy żalów dołóżmy dowolne zmiany wprowadzane czasem w tekst recenzji przez redaktora dyżurnego, który danego filmu nawet nie oglądał7 ${ }^{74}$.

Praktyki tego typu, jak dodaje Morawski, podważają zaufanie czytelników do krytyka i redakcji. Publikowanie krytykowi jedynie pozytywnych recenzji filmów radzieckich sprawia, że jego oceny stają się przewidywalne. Co więcej, zostają wpisane w znany powszechnie schemat propagandowy i sam krytyk staje się w oczach jakiejś grupy czytelników funkcjonariuszem jej aparatu. Być może część czytelników zada sobie pytanie, czy rzeczywiście recenzje odzwierciedlają poglądy ich autora, ale wielu nie będzie miało wątpliwości tego rodzaju. Nie zamierzam dowodzić, że każdy krytyk w PRL-u był bezwolnym wykonawcą odgórnych poleceń, chociaż zapewne i tacy byli. Jaki był zakres niezgody Morawskiego na ograniczenia wolności wypowiedzi, można by wnioskować na podstawie zarchiwizowanych niewydrukowanych recenzji lub ujawnionych ingerencji cenzorskich.

Trzeba jeszcze zwrócić uwagę na to, że nie wszystkie filmy zaakceptowane przez komunistycznych decydentów były odrzucane przez widzów. Lewicowa wymowa nie przekreślała automatycznie każdego utworu. Tak było w przypadku neorealizmu

Zob. A. Helman, Strategia krytyki filmowej, „Kino” 1980, nr 12.

74 S. Morawski, O krytyce filmowej w piśmie ..., op. cit., s. 4. Prawdopodobnie Morawski pisze o filmie dokumentalnym: Feliks Dzierżyński, reż. Eugeniusz Cękalski, prod. 1951, Polska. 
włoskiego. Z jednej strony filmy tego nurtu dobrze wpisywały się w politykę kulturalną PZPR, a z drugiej - były wzorem filmu realistycznego, w którym część krytyków widziała już przed II wojną światową przeciwwagę dla kina gatunku. Dla filmowców zaś stanowiły inspirację w zakresie produkcji filmów w warunkach gospodarki niedoboru, z którą borykali się w Polsce. Rozstrzygnięcie, do jakiego stopnia krytyk szczerze chwali film neorealistyczny, a do jakiego jest to wyraz jego konformizmu wobec systemu politycznego, wymaga każdorazowo indywidualnego podejścia. Nie tylko do osoby, lecz również do sytuacji, w której się znajdowała, pisząc recenzję. Jest to więc zadanie wymagające powiązania różnych, często trudno uchwytnych czynników (np. nastrój krytyka podczas pisania), w wykonaniu którego należy powstrzymywać się przed szybko stawianymi ocenami i jednoznacznymi uogólnieniami.

I tu dochodzę do zaangażowania ideowego. Morawski bierze odpowiedzialność za własne wybory. Wspominając swoją młodość, wyjaśnia:

Marksizm nie był moim przeznaczeniem, mimo że w domu - dzięki pasjom i biblioteczce ojca - zetknąłem się jako chłopiec z lekturą socjalistyczną. Wybrałem ten światopogląd, gdyż wydał mi się po Holocauście najwłaściwszym projektem budowania więzów międzyludzkich w skali globalnej ${ }^{75}$.

Co więcej, dodaje, że również stalinizm-leninizm był jego wyborem. Rozstał się z nim po roku 1956. Z marksizmem pozostał dłużej, ale rozczarowanie narastało stopniowo. Stałym czynnikiem motywującym od lat młodzieńczych jego światopogląd była natomiast duża „wrażliwość na krzywdę społeczną"76. Można przypuszczać, że wrażliwość ta dawała pożywkę postawie etycznej, która znajdowała wyraz także w recenzjach filmowych.

Odnosząc się do kwestii ulokowania refleksji o filmach i krytyce filmowej w kontekście poglądów filozoficznych Stefana Morawskiego, mogę - upraszczając - zaznaczyć, że obcowanie z filmem i namysł nad nim był potrzebny bohaterowi tego szkicu z dwóch powodów. Pierwszym z nich było dążenie do empirycznej weryfikacji tez estetycznych. Do lat 70. XX wieku Morawski tworzył estetykę, która łączyła podejście filozoficzne z naukowym. Argumentował, że podobnie jak tezy nauk szczegółowych rozważania estetyczne muszą być sprawdzane w historycznie ukształtowanej rzeczywistości. Dla estetyki była nią materia sztuki, konkretne dzieła i ich zmysłowa percepcja. Jednocześnie nie ograniczał swoich zainteresowań estetycznych jedynie do jakiegoś rodzaju bądź nurtu sztuki. Co więcej, badając granice refleksji estetycznej, musiał zadawać pytania o granice sztuki i ekspresję wartości artystycznych. Film był więc jednym z pól, na których Morawski mógł napotkać zjawiska niepoddające się konstatacjom estetycznym, co czyniło go szczególnie pociągającym.

\footnotetext{
75 Ofilozofowaniu, perypetiach dzisiejszej kultury i rebus publicis. Ze Stefanem Morawskim rozmawiaja Andrzej Szahaj i Anna Zeidler-Janiszewska, Toruń 1995, s. 65.

76 Ibidem.
} 
Konfrontacja tez estetycznych z filmem nie tylko dawała możliwość poddania ich próbie, lecz również kusiła potencjałem ujawnienia nowych problemów.

Po zetknięciu się z wytworami neoawangardy Morawski zdał sobie sprawę z tego, że podstawowe pojęcia estetyki zostały podważone przez artystów ${ }^{77}$. Na przykład pytanie o wartości kontemplacyjne dzieła sztuki przestało mieć sens. Jak pisze Piotr Jan Przybysz:

Zmiana „koniunktury” z wartości artystycznych na pojęcie twórcy, twórczości, dzieła sztuki i odbiorcy wyznacza nowy horyzont zainteresowań. Fundamentem teraz, jak i poprzednio, są argumenty natury empirystycznej. Tak się zmienia przedmiot poznania i jeżeli dalej chce się kontynuować uprawianą naukę, należy podążać za dokonującymi się przeobrażeniami ${ }^{78}$.

Przemyślenia doprowadziły Morawskiego do wniosku, że w nowej sytuacji twórczość artystyczną należy ujmować w świetle filozofii kultury. Odpowiedzi na pytanie o rozmiary rozprzestrzeniania się antyestetyzmu poszukiwał również w sferze filmu. Podkreślał, że w tym przypadku wciąż można stosować pojęcie mimesis. Owszem są filmy, które negują swoje relacje z rzeczywistością empiryczną, ale równie silnie rozwija się nurt podkreślający autentyzm przedstawianych zdarzeń. Wraz z pojawieniem się postmodernizmu film dla Morawskiego stał się przedmiotem krytyki jako zbyt silnie eksponujący konsumpcyjną i hedonistyczną postawę wobec życia. Na przykładach filmów krytyk starał się wykazać proces rozpadu kultury zachodniej, w której przez masowość i merkantylność rynku ulegają zniszczeniu fundamentalne wartości scalające ją od tysiącleci.

\section{Bibliografia}

Balázs B., Wybór pism, przeł. R. Porges, K. Jung, Filmowa Agencja Wydawnicza, Warszawa 1957.

Bazin A., Film i rzeczywistość, przeł. B. Michałek, Wydawnictwa Artystyczne i Filmowe, Warszawa 1963.

Dreyer R., Za realizmem - przeciw schematom, „Ekran” 1964, nr 25 (376).

Eisenstein S., Nieobojętna przyroda, przeł. M. Kumorek, Wydawnictwa Artystyczne i Filmowe, Warszawa 1975.

Garaudy R., D’un réalisme sans rivages, Plon, Paris 1966.

Helman A., André Bazin [w:] A. Helman, J. Ostaszewski, Historia myśli filmowej. Podręcznik, Słowo/Obraz Terytoria, Gdańsk 2007.

Helman A., Odbicie czy interpretacja, „Ekran” 1964, nr 26 (377).

Helman A., Strategia krytyki filmowej, „Kino” 1980, nr 12

77 Zob. P.J. Przybysz, Filozofia sztuki Stefana Morawskiego, Słowo/Obraz Terytoria, Gdańsk 2010, s. 266-267; P.J. Przybysz, A. Zeidler-Janiszewska, Stefan Morawski - wstepny szkic do portretu [w:] S. Morawski, Wybór pism estetycznych, Universitas, Kraków 2007, s. XVI-XX.

78 P.J. Przybysz, Filozofia sztuki ..., op. cit., s. 267. 
Ingarden R., Kilka uwag o sztuce filmowej [w:] A. Helman (red.), Estetyka i film, Wydawnictwa Artystyczne i Filmowe, Warszawa 1972.

Ingarden R., O dziele literackim. Badania z pogranicza ontologii, teorii języka i filozofii literatury, przeł. [z niem.] M. Turowicz, Państwowe Wydawnictwo Naukowe, Warszawa 1988.

Kracauer S., Teoria filmu. Wyzwolenie materialnej rzeczywistości, przeł. W. Wertenstein, Wydawnictwa Artystyczne i Filmowe, Warszawa 1975.

Krzemień-Ojak S., U źródet, „Ekran” 1964, nr 20 (371).

Mach J., Sprawa treści, „Ekran” 1964, nr 24 (375).

Morawski S., ,, Celuloza”. Film produkcji polskiej, „Gazeta Krakowska” 1954, nr 109 (1738).

Morawski S., ,,Pod gwiazda frygijska”,, „Gazeta Krakowska” 1954, nr 262 (1911).

Morawski S., ,Rzym - godzina 11”. Film produkcji włoskiej, „Gazeta Krakowska” 1954, nr 31 (1680).

Morawski S., ,,Rzym, miasto otwarte”, „Gazeta Krakowska” 1949, nr 59.

Morawski S., ,, Skarb”. Film produkcji polskiej, „Gazeta Krakowska” 1949, nr 16.

Morawski S., ,Stracony weekend”. Film produkcji amerykańskiej, „Gazeta Krakowska” 1949, nr 117.

Morawski S., 20 najlepszych. Ankieta (3), „Kwartalnik Filmowy” 1993, nr 3 (63).

Morawski S., Bez „, wampów” i cieplarnianych twarzy. Styl filmów radzieckich, „Echo Krakowa" 1948, nr 305 (954).

Morawski S., Dlaczego filmy radzieckie sa dobre, „Echo Krakowa” 1948, nr 285 (934).

Morawski S., Jak patrzeć na film, Filmowa Agencja Wydawnicza, Warszawa 1955.

Morawski S., Kino etosu czy akcji, „Kwartalnik Filmowy” 2000 nr 29-30 (89-90).

Morawski S., Kreskówki radzieckie, „Gazeta Krakowska” 1950, nr 101 (416).

Morawski S., Kreskówki, „Gazeta Krakowska” 1954, nr 227 (1876).

Morawski S., Liryczna miłość wśród apaszów, „Polityka” 1958, nr 19 (63).

Morawski S., Nowa czy stara formuła realizmu, „Ekran” 1964, nr 22 (373).

Morawski S., O krytyce filmowej w piśmie codziennym, „Przegląd Kulturalny” 1953, nr 13 (31).

Morawski S., O marksistowskim pojmowaniu realizmu, „Ekran” 1964, nr 21 (372).

Morawski S., O niepokojach XX-wiecznych i tzw. końcu sztuki, „Ekran” 1963, nr 9 (308).

Morawski S., Pytania, formy, odpowiedzi, „Ekran” 1960, nr 2 (144).

Morawski S., Styl Felliniego, „Ekran” 1964, nr 35 (386).

Morawski S., Szkice z podstawowych zagadnień estetyki marksistowskiej, Państwowy Instytut Sztuki, Warszawa 1952.

Morawski S., U podstaw krytyki filmowej, „Kwartalnik Filmowy” 1963, nr 1-2 (49-50).

Morawski S., Uwagi o krytyce filmowej, „Kwartalnik Filmowy” 1951, nr 3-4.

O filozofowaniu, perypetiach dzisiejszej kultury i rebus publicis. Ze Stefanem Morawskim rozmawiają Andrzej Szahaj i Anna Zeidler-Janiszewska, Toruń 1995.

Opoczyńska H. [S. Morawski], Przykazanie a rozkaz, „Ekran” 1960, nr 13 (155).

Przybysz P.J., Filozofia sztuki Stefana Morawskiego, Słowo/Obraz Terytoria, Gdańsk 2010.

Przybysz P.J., Zeidler-Janiszewska A., Stefan Morawski - wstepny szkic do portretu

[w:] S. Morawski, Wybór pism estetycznych, Universitas, Kraków 2007.

Stefanowicz M. [S. Morawski], Różne różności i „Rififi”, „Ekran” 1959, nr 28 (118).

Stefanowicz M. [Stefan Morawski], Trapez, czyli idée fixe, „Ekran” 1959, nr 33 (123). 


\section{Filmografia}

Celuloza, reż. Jerzy Kawalerowicz, prod. 1953, prem. 27 kwietnia 1954, Polska.

Fantazja (Fantasia), reż. James Algar, Samuel Armstrong, Ford Beebe Jr., Norm Ferguson,

David Hand, Jim Handley, Thornton Hee, Wilfred Jackson, Hamilton Luske, Bill Roberts,

Paul Satterfield, Ben Sharpsteen, prod. 1940, prem. 19 września 1941, USA.

Feliks Dzierżyński, reż. Eugeniusz Cękalski, prod. 1951, Polska.

Monsieur Verdoux, reż. Charles Chaplin, prod. 1947, prem. 11 kwietnia 1947, USA.

Nietolerancja (Intolerance: Love's Struggle Throughout the Ages), reż. David Wark Griffith, prod. 1916, prem. 5 września 1916, USA.

Pod gwiazda frygijska, reż. Jerzy Kawalerowicz, prod. 1954, prem. 30 października 1954, Polska.

Rififi (Du rififi chez les hommes), reż. Jules Dassin, prod. 1955, prem. 13 kwietnia 1955, Francja.

Rozkaz: zabić (Orders to Kill), reż. Anthony Asquith, prod. 1958, prem. 13 kwietnia 1958, Wielka Brytania.

Rzym, godzina 11 (Roma, ore undici), reż. Giuseppe De Santis, prod. 1952, prem. 28 grudnia 1952, Francja/Włochy.

Rzym, miasto otwarte (Roma, città aperta), reż. Roberto Rossellini, prod. 1945, prem.

25 września 1945, Włochy.

Skarb, reż. Marian Leonard [Leonard Buczkowski], prod. 1948, prem. 15 lutego 1949, Polska.

Słodkie życie (La dolce vita), reż. Federico Fellini, prod. 1960, prem. 3 lutego 1960, Włochy.

Stracony weekend (The Lost Weekend), reż. Billy Wilder, prod. 1945, prem. 29 listopada 1945,

USA.

Trapez (Trapeze), reż. Carol Reed, prod. 1956, prem. 30 maja 1956, USA.

Turksib, reż. Wiktor Turin, prod. 1929, prem. 15 października 1929, ZSRR.

Złoty kask (Casque d'or), reż. Jacques Becker, prod. 1952, prem. 13 marca 1952, Francja. 